\title{
Jaringan Islamisasi Gorontalo (Fenomena Keagamaan dan Perkembangan Islam di Gorontalo)
}

\author{
Mashadi Maili \& Wahidah Suryani \\ IAIN Sultan Amai Gorontalo
}

\begin{abstract}
In this article, the authors argue that Gorontalo Municipality, which is believed to have been founded as the centre of government since 1728 AD, or precisely in 6 Sya'ban 1140 H., has become an "Islamic city". Sultan Amai, in 1525, is believed to be the first place to the cornerstone of Islam in this country. The king Matolodulakiki made Islam as the official religion of the kingdom during his reign by prioritizing the principle: "Adati hula-hulaa to saraa, saraa hula-hulaa to Qur'ani". The king Eyato then refined the principle of Islamic and state fusion and adat since 1673. Furthermore, Sultan Botutihe emphasized the process of Islamization by moving the centre of government from Dungingi to a new location, which is currently the complex area of the Great Baiturrahim Mosque in Gorontalo municipality. This mosque is a historical landmark of the government and the centre of religion. Implicitly this means that the relationship between state, religion and adat has been so strong in Gorontalo. The principle of the spread of Islam at this time endures to a new development, namely "custom in Islam or Islam that is imposed". Furthermore, the network of Islamization in the 19th century until the present era mainly marked by the establishment of several organizations and institutions such as: Al-Huda, Al-Khairat, Muhammadiyah and NU.
\end{abstract}

\begin{abstract}
Abstrak
Dalam artikel ini, para penulis berpendapat bahwa Kota Gorontalo yang diperkirakan lahir sebagai pusat pemerintahan sejak tahun 1728 M, atau tepatnya 06 Sya'ban $1140 \mathrm{H}$ telah menjadi "kota Islam". Sultan Amai, raja dari utara yang ke II Kerajaan Gorontalo pada tahun 1525 diyakini menjadi peletak pertama tonggak Islam di negeri ini. Raja Matolodulakiki menjadikan Islam sebagai agama resmi kerajaan pada zaman pemerintahannya, dengan prinsip: "Adati hula-hulaa to saraa, saraa hula-hulaa to Qur'ani". Peleburan Islam dan negara dan adat lantas disempurnakan oleh Raja Eyato, sejak tahun 1673. Selanjutnya, Sultan Botutihe menengaskan proses islamisasi dengan memindahkan pusat pemerintahan dari Dungingi ke lokasi baru, yakni kawasan kompleks Mesjid Agung Baiturrahim Kota Gorontalo saat ini. Mesjid ini kemudian menjadi tonggak sejarah pemerintahan dan pusat agama. Secara empiris dapat dikatakan bahwa hubungan antara negara, agama dan adat sudah sedemikian kuat di Gorontalo. Prinsip penyebaran Islam pada masa ini melahirkan suatu perkembangan baru yakni "adat yang di Islam-kan atau Islam yang diadat-kan". Selanjutnya, jaringan Islamisasi pada abad ke-19 sampai zaman sekarang ditandai dengan berdirinya beberapa organisasi dan institusi seperti: AL-Huda, Al-Khairat, Muhammadiyah dan NU.
\end{abstract}

Kata Kunci: Islam, Gorontalo, islamisasi, AL-Huda, Al-Khairat, Muhammadiyah, NU.

Author correspondence

Email: mashadi@iaingorontalo.ac.id

Available online at http://journal.iaingorontalo.ac.id/index.php/au/index 


\section{A. Pendahuluan}

Berbagai kajian mengenai islamisasi nusantara memperlihatkan suatu kesimpulan paradigmatis bahwa peta penyebaran Islam nusantara berasal dari jalur Gujarat ke samudra Pasai, dan seterusnya minangkabau, Palembang, hingga seterusnya ke tanah Jawa, dan seterusnya keseluruh bumi nusantara.

Namun disisi lain para sejarawan berbeda pendapat dan hingga kini belum tuntas mengenai masuk dan datangnya Islam di Nusantara, meski dalam beberapa sisi sudah ada titik temu. Hal ini berkaitan dengan tiga masalah pokok: tempat asal kedatangan Islam, para pembawa Islam dan waktu kedatangannya. Perbedaan ini muncul karena kurangnya informasi dari sumber-sumber yang telah ada, termasuk adanya sebagian sejarawan maupun penulis sejarah yang mendukung atau menolak teori tertentu. Azyumardi Azra lebih lanjut menjelaskan bahwa terdapat kecenderungan kuat suatu teori tertentu menekankan hanya aspek-aspek khusus dari tiga masalah pokok, sementara mengabaikan aspek-aspek lainnya.Karena itu, kebanyakan teori yang ada dalam sisi-sisi tertentu gagal menjelaskan kedatangan Islam, kapan konversi agama penduduk local terjadi, dan proses-proses islamisasi yang terlibat di dalamnya. Bahkan bukannya tidak bisa jika suatu teori tidak mampu menjawab pertanyaan-pertanyaan tandingan yang diajukan dari teori-teori lain ${ }^{1}$.

Provinsi Gorontalo merupakan daerah yang memiliki kebudayaan yang beraneka ragam serta suku yang majemuk. Sehingga agama yang berkembang di Provinsi ini menjadi beragam pula, diantaranya Islam, Protestan, Katholik, Hindu dan Budha. Tapi yang banyak di anut penduduk gorontalo adalah agama Islam. Orang Gorontalo hampir dapat dikatakan semuanya beragama Islam (96.36 \%) yang sesuai falsafah daerah ini: "Adati hula to syaraa; syaraa hulahula to Qurani" atau "Adat bersendikan sara', sara' bersendikan kitabullah". Gorontalo pun di kenal dengan sebutan "Kota Serambi Madinah" dengan infrastruktur serta bentuk bentuk bangunannya yang bernuansa islami. Sebelum kedatangan agama Islam, penduduk Gorontalo memeluk agama Alifuru, semacam kepercayaan animisme

\footnotetext{
${ }^{1}$ Azyumardi Azra. 1994. Perspektif Islam di Asia Tenggara (Jakarta: Yayasan Obor. h. vi
} 
dan dinamisme ${ }^{2}$. Serta mempunyai tiga bahasa daerah, yaitu Bahasa Gorontalo, Suwawa, dan Atinggola. Saat ini, bahasa yang lebih banyak dipakai sehari-hari adalah bahasa Indonesia dialek Manado, logat Gorontalo.

Sesuai peta penyebaran agama Islam di Nusantara oleh Tugiyono, bahwa pusat dan sumber penyebarannya adalah kerajaan Ternate, sebagai kerajaan Islam yang timbul di bagian timur Indonesia sejak tahun 1430 M. Perlu dicatat bahwa Islam dari Ternate menuju pantai Timur Sulawesi pada awalnya memasuki kawasan Tomini ke daerah Palasa yang sudah dikenal sejak abad ke 15 pada saat itu sebelum bernama Tinombo3 ${ }^{3}$ Menurut A. Mopangga bahwa Islam dimasukkan dan disebarkan oleh muballigh Ternate pada abad ke XIV.Muballigh tersebut sewaktu kembali dari Aceh mempelajari aqidah Islam, kesasar dalam perjalan pulang ke Ternate terbawa arus ombak laut ke teluk Tomini, Palasa bukan ke Gorontalo4.

Konteks demikian mengkonfirmasi bahwa masuknya Islam ke Gorontalo punya kaitan erat dengan keberadaan Teluk Tomini Barat, yakni daerah Palasa yang sudah terkenal pada saat itu, terutama masa abad ke 15 dan 16. Menurut Kuno Kaluku ${ }^{5}$ yang juga berpandangan bahwa pada tahun 1430, raja Gorontalo yang bernama Walango berangkat ke Teluk Tomini Barat, daerah Palasa untuk membuka tanah-tanah perkebunan. Sementara Raja pengganti Walango yaitu Polamolo, melakukan pula perjalanan ke daerah itu dengan tujuan yang sama. Dan Polamolo sempat menikah dengan perempuan lokal di Palasa. Dalam kaitan tersebut S.R. Nur ${ }^{6}$ mengungkapkan bahwa raja Amai, raja utara yang ke II kerajaan Gorontalo pada tahun 1525, melakukan perjalanan dinasnya ke daerah-daerah

\footnotetext{
2Pendapat tersebut tidak disepakati oleh Wantogia, yang menurutnya sejak semula orang Gorontalo percaya pada Tuhan yang maha Esa. Ungkapan dalam bahasa Suwawa-Gorontalo "Taquwata to mita niya Eya tuwawu loqu tuwawu liyo" (Tuhan yang maha Esa dan ke-maha-esa-an Tuhan, Tuhan Tunggal sebenar-benarnya tunggal) lihat Olha S. Niode: 2014 dalam S.Kau: 2015: 13. Menurut Kau dan Suleman, sebutan Tuhan dalam bahsa Gorontalo disebut "Eya". Kata "Eya" berdekatan dengan kata Esa dalam bahasa Indonesia (yang sebelumnya berasal dari bahasa Sansekerta). Menurut mereka, boleh jadi juga kata "Eya" berasal dari kata Arab "iyyahu" (hanya kepada-Nya). Lebih lanjut dalam konteks ini Wantogia menegaskan bahwa orang Gorontalo tidak pernah menyembah batu, gunung, pohon, air, dan sebagainya. Mereka hanya percaya pada roh-roh halus yang bersemayam dalam benda-benda itu.

${ }^{3}$ Tugiyono. 1982 Atlas dan Lukisan Sejarah Nasional Indonesia. CV. Baru; Jakarta, h. 72

${ }^{4}$ Mopangga, A. 1997. Sejarah Kampung Empat; Siduan, Sipayo, Soginti, Bunuyo. (Makalah). h. 1

${ }^{5}$ Kuno Kaluku. Adat dan Agama Islam. (T.T. T.P. Gorontalo). h. 34

${ }^{6}$ S.R. Nur. 1996. Islam dan Etos Kerja Masyarakat Gorontalo. Yayasan Festival Istiqlal: Jakarta. h.131.
} 
jajahan Gorontalo di Teluk Tomini Barat dan kawin disana, daerah Palasa. Dalam perjalanan dinasnya di Palasa, Sultan Amai bertemu dengan puteri Raja Palasa (bergelar Ogomonjolo; yang punya sifat air dingin) yang bernama Owutango, yang sudah menerima Islam dari Kesultanan Ternate.

Islamisasi adalah sebuah proses sejarah umat manusia tentang kepercayaannya yang sejatinya tidak berhenti, yang dalam gagasan M.C. Rieckfles (1981) disebut sebagai a process, which has continued ${ }^{7}$, yakni sejak datangnya Islam pertama kali, penerimaan dan penyebarannya hingga kini. Lebih lanjut berkaitan dengan konteks tersebut, Noorduyn dalam karyanya "De Islamisering" sebagaimana dikutip oleh A.M. Sewang, mengungkapkan bahwa terdapat tiga tahapan dalam proses Islamisasi; pertama; datangnya agama Islam, yakni tibanya agama Islam saat pertama kali di suatu wilayah, kedua; masuknya agama Islam, yakni penduduk diwilayah tersebut telah memeluk agama Islam, dan ketiga; penyebaran agama Islam, yaitu Islam mulai disebarkan kepada masyarakat atau keluar wilayah dimana Islam diterima pertama kali ${ }^{8}$.

Dipilihnya Kota Gorontalo sebagai lokasi penelitian, adalah karena Kota Gorontalo merupakan pusat kota provinsi Gorontalo. Kota yang dikenal dengan falsafah: "Adati hula to syaraa, syaraa hulahula to Qurani" atau "Adat bersendi syara, syara bersendi al-Qur'an",9 ini juga dikenal sebagai: "Kota Serambi Madinah". Kota ini dihuni oleh penduduk yang mayoritas beragama Islam (96,3\%). Sesuai dengan falsafahnya, tampak bahwa Kota Gorontalo sangat ketat dalam mengamalkan ajaran agama Islam, sekaligus juga kukuh dalam mepertahankan adat dan tradisi yang sejalan dengan ajaran Islam. Meskipun Islam adalah agama yang mayoritas namun tidak berarti bahwa agama lain tidak eksis. Agama Kristen, Katolik, Hindu, dan Budha tetap eksis sebagai satu entitas keagamaan meskipun dalam segi jumlah mereka adalah minoritas. Kota ini menjadi pusat tempat penelitian ini dilakukan sebagai obyek dan lokus utama dari studi ini.

\footnotetext{
${ }^{7}$ Ahmad M. Sewang. 2005. Islamisasi Kerajaan Gowa: Abad XVI sampai abad XVII. Yayasan Obor Indonesia: Jakarta., h. 5

${ }^{8}$ A.M. Sewang. Ibid., h. 6

${ }^{9}$ Moh. Ihsan Husnan, Pohutu Momulanga: gelar adat di Gorontalo, Al-Ulum, vol. 12, no.1, h. 175; lihat Muhiddin Bakry, Nilai religiousitas adat Mo Me'ati pada masyarakat Kota Gorontalo (Replika Islam Nusantara), Al-Ulum, 2016, vol. 16, no.2, hal. 185. Lihat juga M Gazali Rahman, Tradisi Mothulo di Gorontalo, Al-Ulum, 2012, vol.12, no. 2, hal. 443.
} 
Berdasarkaan konteks latar belakang tersebut, maka menjadi niscaya untuk mengungkap sisi lain dari proses islamisasi di bumi Hulondhalo, utamanya yang berkaitan dengan jaringan islamisasi Gorontalo, apakah semata mata pengaruh Islam Ternate atau hadir pula factor factor determinan lain dalam proses itu. Di samping itu tidak terungkap secara memadai dari data yang telah ada saat ini berkaitan mengapa Olongia Amai tidak menjadikan Islam sebagai Agama kerajaan, yang dalam konteks tersebut menisbikan kerjaan Gorontalo disebut sebagai kerajaan Islam Gorontalo, yang mana terdapat sultan yang berkuasa di dalamnya.

Secara paradigmatis, studi ini berada pada posisi konstruktivisme, yang mana realitas itu ada sebagai hasil konstruksi dari kemampuan berpikir manusia. Guba mengungkapkan bahwa paradigama konstruktivisme dalam penelitian memandang realitas tidak bebas nilai. Realitas hanya dapat diteliti dengan pandangan yang berdasarkan nilai. Pengetahuan merupakan konsekwensi dari aktivitas manusia yang mengkonstruksi realitas, dan hasilnya bukan merupakan kebenaran yang tetap, namun dia akan menjadi pengetahuan yang berkembang secara terus-menerus. Studi ini menggunakan pendekatan sejarah keagamaan, antropologis dan fenomenologis. Karakteristik dasar pendekatan antropologis adalah holism, yakni pandangan bahwa praktik-praktik social harus diteliti dalam konteks dan secara esensial dilihat sebagai praktek yang berkaitan dengan yang lain dalam masyarakat yang sedang diteliti. Para antropolog harus memandang agama dan praktik-praktik social lainnya secara bersama-sama dalam satu kesatuan yang utuh ${ }^{10}$. Adapun pendekatan fenomenologis dalam riset agama dimaksudkan untuk mendeskripsikan pengalaman-pengalaman agama se-akurat mungkin. Dalam penggambaran, analisa dan interpretasi makna, ia berupaya untuk menunda penilaian tentang apa yang riil atau tidak riil dalam pengalaman orang lain. Ia berupaya menggambarkan, memahami dan berlaku adil kepada fenomena agama seperti yang muncul dalam pengalaman keberagamaan orang lain ${ }^{11}$.

Dalam kerangka studi agama, di Kota Gorontalo ditemukan suatu suasana sosial dan keagamaan yang menarik. Hal ini mengingat Kota Gorontalo merupakan

${ }^{10}$ Peter Connolly (ed.) 2011. Aneka Pendekatan Studi Agama. Yogyakarta. LKiS., h. 34.

11 Rusli. 2008, h. 144. 
wilayah yang sangat menjunjung tinggi kebudayaan lokal yang diwariskan oleh para pendahulu. Di samping itu peran agama juga sangat kuat memberikan pengaruh yang signifikan bagi kehidupan bermasyarakat di Kota Gorontalo, utamanya Islam yang dianut oleh sekitar 96,36\% penduduk Gorontalo. Sementara 3,64\% selebihnya adalah penganut Kristen Protestan sebanayak 2,42 persen, Katolik sebanyak 0,56 persen, Hindu 0,59 persen, dan Budha 0,07 persen (BPS Kota Gorontalo 2015). Dari data tersebut jelas bahwa penduduk Kota Gorontalo mayoritas beragama Islam. Penganut agama lain yang merupakan minoritas bisa hidup harmonis dengan penduduk bergama Islam yang merupakan mayoritas. Konflik yang mengatasnamakan agama belum pernah terjadi di Gorontalo, hal ini membuktikan bahwa toleransi antar ummat beragama bisa terjaga dengan baik. Dengan jumlah pemeluk agama yang tersebut diatas, dibarengi dengan pertambahan jumlah sarana peribadatan yang cukup signifikan.

Sarana ibadah merupakan refresentasi buat pemeluk agama-agama yang ada. Kota Gorontalo yang memiliki penganut agama Islam yang begitu besar sangatlah wajar bila memiliki mesjid yang juga banyak, yakni 277 mesjid yang tersebar di seluruh penjuru kota, selain itu terdapat 4 buah Mushollah (BPS Kota Gorontalo 2015).

\section{B. Jaringan Islamisasi di Gorontalo pada Masa Awal Keislaman (Islamisasi Fase Pertama: 1525-1679).}

Para sejarawan berbeda pendapat dan hingga kini belum tuntas mengenai masuk dan datangnya Islam di Nusantara, meski dalam beberapa sisi sudah ada titik temu. Hal ini berkaitan dengan tiga masalah pokok yaitu tempat asal kedatangan Islam, para pembawa Islam dan waktu kedatangannya. Perbedaan ini muncul karena kurangnya informasi dari sumber-sumber yang telah ada, termasuk adanya sebagian sejarawan maupun penulis sejarah yang mendukung atau menolak teori tertentu. Azyumardi Azra lebih lanjut menjelaskan bahwa terdapat kecenderungan kuat suatu teori tertentu menekankan hanya aspek-aspek khusus dari tiga masalah pokok, sementara mengabaikan aspek-aspek lainnya. Karena itu, kebanyakan teori yang ada dalam sisi-sisi tertentu gagal menjelaskan kedatangan Islam, kapan konversi agama penduduk local terjadi, dan proses-proses islamisasi yang terlibat di dalamnya. Bahkan bukannya tidak bisa jika suatu teori tidak 
mampu menjawab pertanyaan-pertanyaan tandingan yang diajukan dari teoriteori lain ${ }^{12}$.

Gorontalo merupakan salah satu pusat penyebaran agama Islam di Indonesia Timur, selain Ternate, Gowa dan Bone. Penyebaran Islam ke Gorontalo kemungkinan ada sejak abad ke 14 ditandai dengan adanya salah satu tokoh penyebaran agama Islam di Gorontalo yakni Sutan Amai, kemudian diteruskan oleh raja - raja Gorontalo pada abad ke-15. Menurut Ibrahim Polontalo bahwa proses awal masuknya Islam ke Gorontalo hanya melalui satu jalur saja yaitu perkawinan antara raja (olongia) Gorontalo, Amai ${ }^{13}$ dengan puteri raja Ogomanjolo, Palasa, Tomini yang bernama Owutango pada tahun $1525^{14}$. Kala itu, Sultan Amai (1503 - 1585) yang menjadi Raja Gorontalo pergi ke Palasa di Sulawesi Tengah. Di situ, ia jatuh cinta kepada putri kerajaan Gomonjolo, Putri Owutango. Putri Owutango memberi syarat kepada Amai, apabila mau menikahinya, anak keturunan Sultan Amai dan seluruh rakyat Gorontalo harus memeluk Islam.Amai pun menjalankan permintaan ini dan berusaha memasuki setiap sisi kehidupan masyarakat. Institusi pendidikan, keluarga, seni dan budaya dimanfaatkannya untuk mensosialisasikan Islam.

Sejak awal masehi kawasan Asia Tenggara telah berfungsi sebagai jalur lintas perdagangan bagi kawasan sekitarnya, Asia Timur dan Asia Selatan.Dari kawasan Asia Selatan, hubungan pelayaran antarbenua terus berlanjut ke Barat sebelum akhirnya mencapai Eropa.Melalui jalur perdagangan ini, kawasan Asia tenggara pada abad-abad berikutnya, terutama pada abad ke-5 M menjadi lebih ramai dengan hadirnya para pedagang dan pelaut yang melintasi wilayah tersebut. Maka tak heran apabila waktu itu beberapa bandar di Asia Tenggara seperti Lamuri di Aceh dan Perlak di Aceh Timur, Kedah di Malaysia, Martavan dan Pegu di Myanmar, Ayuthia di Thailand dan Pandurangga di Vietnam, berubah fungsi menjadi bandar regional. Dampak dari komunikasi internasional ini adalah masuknya pengaruh tradisi besar ke kawasan Asia Tenggara, seperti Hindu-Budha

\footnotetext{
${ }^{12}$ Azyumardi Azra. 1994. Jaringan Ulama Timur Tengah dan Kepulauan Nusantara Abad XVII \& XVIII. Jakarta. Prenada Media: Cet. III., h.

${ }^{13}$ Sultan Amai adalah putra dari raja Dedu yang menggantikan ayahnya sebagai Raja (Olongia) pada tahun 1503. Lihat: Zohra Yasin dkk. 2013. Islam Tradisi dan Kearifan Lokal Gorontalo. Gorontalo; Sultan Amai Press., h. 101. Lihat juga Muh. Rusli (2015). Persepsi Masyarakat tentang Makam Raja dan Wali Gorontalo. El-Harakah Vol. 18 No. 1, h. 77

${ }^{14}$ Ibrahim Polontalo. 1968. Peranan Tidi Lopolopalo Gorontalo dalam Pembinaan Kepribadian Suku Gorontalo, (Menado: FKPS-IKIP). h.9
} 
(abad 1-5 M), Islam (abad ke-7-13 M), dan Eropa (abad $17 \mathrm{M}$ ) sejalan dengan kolonialisme di Indonesia dan Asia Tenggara umumnya.

Meski Sultan Amai belum menjadikan Islam sebagai agama resmi kerajaan, namun usahanya sudah melebihi daripada itu yaitu memasyarakatkan Islam lewat delapan orang muballigh yang datang dari kerajaan Ogomanjolo, serta mengislamkan masyarakat dengan jalan mendirikan mesjid pertama dari Gorontalo yang dikena dengan nama mesjid Hunto kemudian berganti nama menjadi mesjid Sultan Amai, serta merancang 188 macam adat yang bernafaskan Islam. Raja Amai menjadi lebih dikenal sebagai Sultan Amai (Jabatan dalam Bahasa Islam) ${ }^{15}$.Perilaku sosial masyarakat yang semula diatur dan diarahkan menurut adat yang bersumber dari alam sejak saat itu mulai berakulturasi dengan nilai-nilai Islam. Prinsip sara' bersendikan adat memperlancar proses tersebut.

Provinsi Gorontalo merupakan daerah yang memiliki kebudayaan yang beraneka ragam serta suku yang majemuk. Sehingga agama yang berkembang di Provinsi ini menjadi beragam pula, diantaranya Islam, Protestan, Katholik, Hindu dan Budha. Agama yang banyak di anut penduduk gorontalo adalah agama Islam. Orang Gorontalo hampir dapat dikatakan semuanya beragama Islam (96.36 \%) yang sesuai falsafah daerah ini, “adat bersendikan sara', sara' bersendikan kitabullah". Gorontalo pun di kenal dengan sebutan "Kota Serambi Madinah" dengan infrastruktur serta bentuk - bentuk bangunannya yang bernuansa islami. Sebelum kedatangan agama Islam, penduduk Gorontalo memeluk agama local, seperti Alifuru, semacam kepercayaan animisme dan dinamisme ${ }^{16}$.

\footnotetext{
15Ibrahim Polontalo. 1997. Proses Masuk dan Berkembangnya Agama Islam di Gorontalo, Makalah.h. 5

16 Pendapat tersebut tidak disepakati oleh Wantogia, yang menurutnya sejak semula orang Gorontalo percaya pada Tuhan yang maha Esa. Ungkapan dalam bahasa Suwawa-Gorontalo "Taquwata to mita niya Eya tuwawu loqu tuwawu liyo" (Tuhan yang maha Esa dan kemahaesaan Tuhan, Tuhan Tunggal sebenar-benarnya tunggal) lihat Olha S. Niode: 2014 dalam S. Kau: 2015: 13. Menurut Sofyan Kau sebutan Tuhan dalam bahsa Gorontalo disebut "Eya". Kata "Eya" berdekatan dengan kata Esa dalam bahasa Indonesia (yang sebelumnya berasal dari bahasa Sansekerta). Menurutnya boleh jadi juga kata "Eya" berasal dari kata Arab "iyyahu" (hanya kepadaNya). Lebih lanjut dalam konteks ini Wantogia menegaskan bahwa orang Gorontalo tidak pernah menyembah batu, gunung, pohon, air, dan sebagainya. Meeka hanya percaya pada roh-roh halus yang bersemayam dalam benda-benda itu.
} 
Jaringan Islamisasi Gorontalo

(Fenomena Keagamaan dan Perkembangan Islam di Gorontalo)

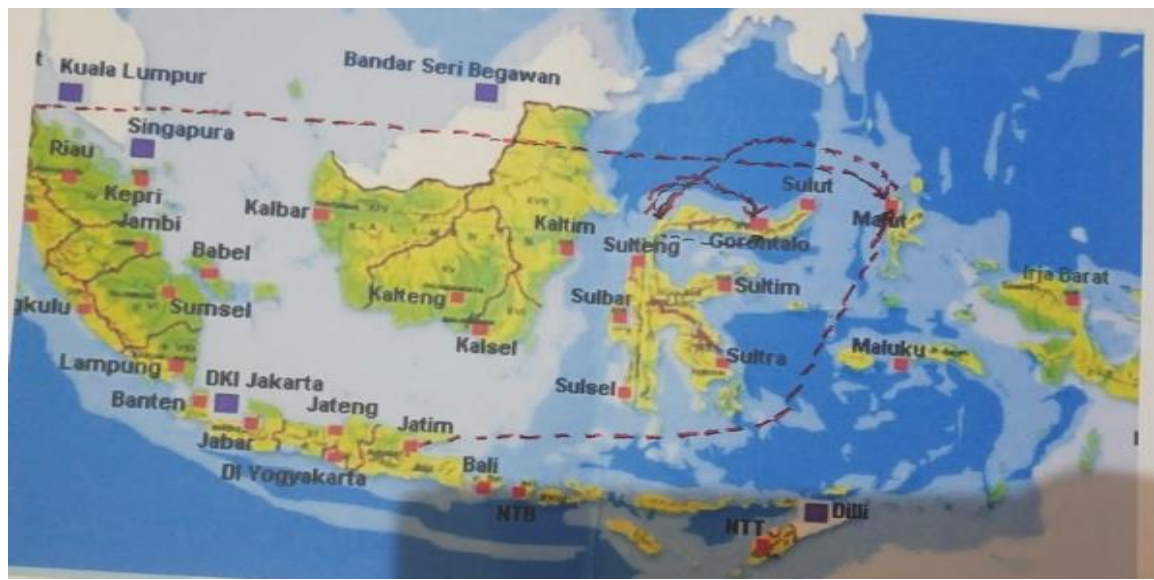

Gambar 1: Peta Islamisasi di Gorontalo Fase Pertama, Sumber: Tugiyono, 1982.

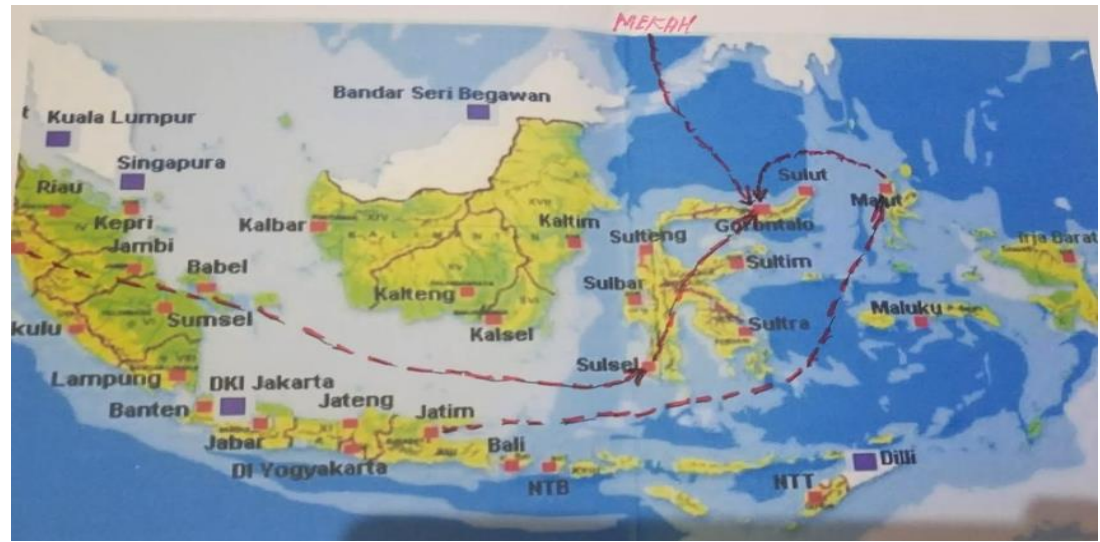

Gambar 2: Peta Islamisasi di Gorontalo Fase Kedua, Sumber: Tugiyono, 1982.

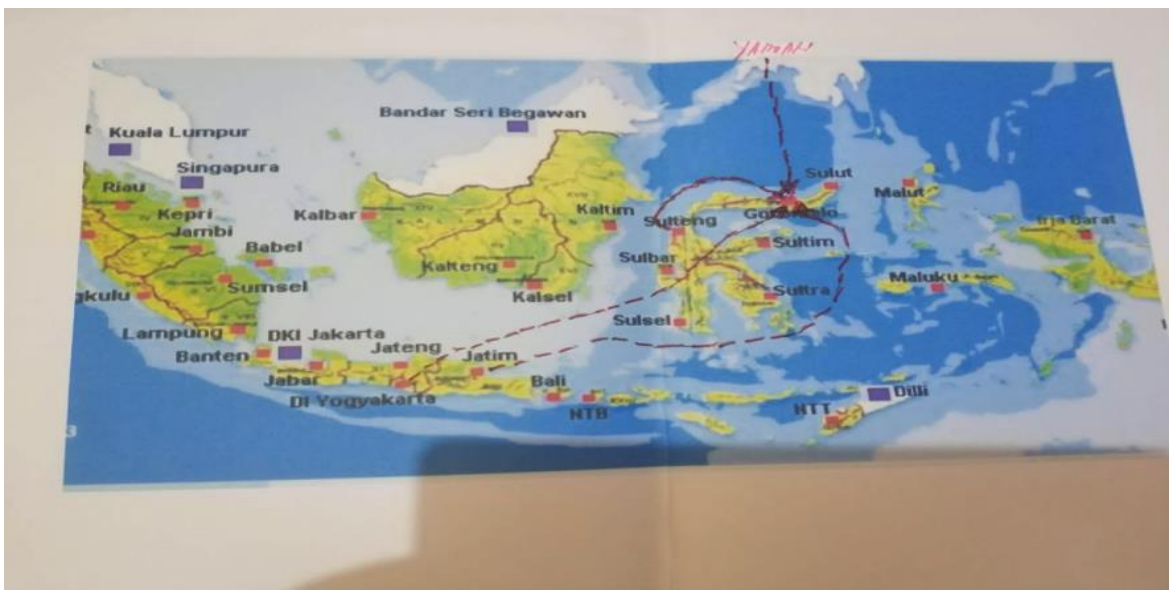

Gambar 3: Peta Islamisasi di Gorontalo Fase Ketiga, Sumber: Tugiyono, 1982.

Berdasarkan peta-peta penyebaran agama Islam di Nusantara oleh Tugiyono di atas, dipahami bahwa pusat dan sumber penyebarannya adalah 
kerajaan Ternate, sebagai kerajaan Islam yang timbul di bagian timur Indonesia sejak tahun $1430 \mathrm{M}$. Perlu dicatat bahwa Islam dari Ternate menuju pantai Timur Sulawesi pada awalnya memasuki kawasan Tomini ke daerah Palasa yang sudah dikenal sejak abad ke 15 pada saat itu sebelum bernama Tinombo17. Menurut Mopangga, Islam dimasukkan dan disebarkan oleh muballigh Ternate pada abad ke XIV. Muballigh tersebut sewaktu kembali dari Aceh mempelajari aqidah Islam, yang kesasar dalam perjalan pulang ke Ternate, terbawa arus ombak laut ke teluk Tomini, Palasa dan bukannya ke Gorontalo ${ }^{18}$.

Konteks demikian mengkonfirmasi bahwa masuknya Islam ke Gorontalo punya kaitan erat dengan keberadaan Teluk Tomini Barat, yakni daerah Palasa yang sudah terkenal pada saat itu, terutama masa abad ke 15 dan 16. Menurut Kuno Kaluku (h.34) yang juga berpandangan bahwa pada tahun 1430, raja Gorontalo yang bernama Walango berangkat ke Teluk Tomini Barat, daerah Palasa untuk membuka tanah-tanah perkebunan. Sementara raja pengganti Walango yaitu polamolo, melakukan pula perjalanan ke daerah itu dengan maksud yang sama, dan dia sempat kawin di Palasa. Dalam kaitan tersebut S.R. Nur19 mengungkapkan bahwa raja Amai, raja utara yang ke II kerajaan Gorontalo pada tahun 1525, melakukan perjalanan dinasnya ke daerah-daerah jajahan Gorontalo tersebut, yakni di Teluk Tomini Barat dan kawin disana, tepatnya di daerah Palasa. Dalam perjalanan dinasnya di Palasa tersebut, Sultan Amai bertemu dengan puteri raja Palasa (bergelar Ogomonjolo; bermakna "yang punya sifat air dingin") yang bernama Owutango, yang sudah menerima Islam dari Kesultanan Ternate.

Islam menjadi agama resmi kerajaan pada zaman pemerintahan Raja Matolodulakiki, yang mengedepankan prinsip "adat bersendi syara', syara bersendi kitabullah". Prinsip penyebaran Islam pada masa ini melahirkan suatu perkembangan baru yakni "adat yang di Islam-kan atau Islam yang diadat-kan”.

Prinsip di atas lantas disempurnakan oleh Eyato, raja Gorontalo, sejak tahun 1673 menjadi " Adati hula-hulaa to saraa, saraa hula-hulaa to Qur'ani" (ASQ). Landasan ini membawa implikasi tak ada lagi pertentangan antara apa yang diajarkan oleh adat dan Islam. Wujud dari landasan tersebut tergambarkan dalam

\footnotetext{
17Tugiyono. 1982 Atlas dan Lukisan Sejarah Nasional Indonesia. CV. Baru; Jakarta ${ }^{18}$ Mopangga, A. 1997. Sejarah Kampung Empat; Siduan, Sipayo, Soginti, Bunuyo. (Makalah)., h. 1

${ }^{19}$ Nur, S.R. 1996. Islam dan Etos Kerja Masyarakat Gorontalo. Yayasan Festival Istiqlal: Jakarta., h. 131
} 
sistem sosial dan pemerintahan yang dibangun oleh Raja Eyato. Konsep kekuasaan Eyato ada dua, yaitu kekuasaan lahir yang dipraktikkan sehari-hari dan kekuasaan batin yang ada di dalam masyarakat. Namun, yang utama dari dua kekuasaan tersebut adalah kekuasaan batin. Ini berarti penguasa harus memusatkan kerjanya kepada kepentingan masyarakat.

Keyakinan terhadap nilai-nilai kebenaran dan kebaikan yang bersumber dari ajaran agama sangat lekat dengan kehidupan religius masyarakat Gorontalo yang menjunjung tinggi falsafah "adat bersendi syara' dan syara' bersendi kitabullah". Seiring dengan penyebaran agama tersebut, Gorontalo menjadi pusat pendidikan dan perdagangan masyarakat di wilayah sekitar seperti Bolaang Mongondow (Sulawesi Utara), Buol Toli-Toli, Luwuk Banggai, Donggala (Sulteng) bahkan sampai ke Sulawesi Tenggara karena letaknya yang strategis menghadap Teluk Tomini (bagian selatan) dan Laut Sulawesi (bagian utara).

Sejarah penyebaran agama Islam di Gorontalo juga ditandai dengan berdirinya Masjid Baiturrahim sejak abad ke-18. Masjid ini didirikan bersamaan dengan pembangunan Kota Gorontalo yang baru dipindahkan dari Dungingi ke Kota Gorontalo saat ini pada tahun 1726 oleh Paduka Raja Botutihe. Sebagai bagian dari Pusat Pemerintahan Kerajaan, fasilitas lain yang turut dibangun yaitu Yiladiya (Rumah Raja), Bantayo Pobuboide (Balairung/Balai Musyawarah), Loji (Rumah kediaman Apitaluwu (Pejabat Keamanan Kerajaan), dan Bele Biya/Bele Tolotuhu, yakni rumah-rumah pejabat kerajaan.

\section{Jaringan Islamisasi di Gorontalo pada Masa Perkembangan Berdasarkan Realitas Keagamaan (Islamisasi: 1920-1980)}

Perkembangan Islam Gorontalo diabad 20 (abad ke tiga islamisasi Gorontalo) tidak lepas dari peran Organisasi kemasyarakatan Islam (ormas) yang meliputi Muhammadiyah, al-Huda, al-Khairat, dan Nahdatul Ulama. Keempat ormas Islam tersebut, secara historis memiliki perannya masing-masing yang cukup kuat dalam konteks mengembangkan Islam di tanah Hulondhalo.

\section{Muhammadiyah}

Pada tahun 1921 setelah penguasa Hindia Belanda menerbitkan surat Gouvernement Besluit nomor 36 tanggal 2 September 1921, yang berisi tentang persetujuan pemerintah Hindia Belanda atas 3 (tiga) perubahan artikel statute Muhammadiyah, yang antara lain memuat tentang bolehnya Muhammadiyah 
mendirikan afdeeling diluar afdeeling Moehammadijah Jogjakarta yang dikepalai oleh Bestuur afdeeling 20 .

Proses masuknya Muhammadiyah ke Gorontalo diawali pada tahun 1929 awal, ketika seorang putera daerah Gorontalo (Jusuf Otoluwa) kembali ke Gorontalo setelah selesai mengikuti pendidikan guru Kweekschool Gunung Sari di Jogjakarta ${ }^{21}$. Ditambah dengan beberapa orang simpatisan, maka pada pertengahan tahun 1929 terbentuklah Muhammadiyah Gorontalo oleh tokohtokoh seperti: Jusuf Otoluwa, Umar Basalamah, Hj. Muhammad Said, Utina H. Buluati, Ahmad Budji, Mohammad Dunggia, Tom Olii, Bouwe Nasaru, Husain Akase, Muhsin Muhammad, and Abdullah Von Grey or locally called Haji Walanda.

Melalui rapat comite bersama para simpatisan, maka terbentuklah pengurus Cabang Muhammadiyah pertama, yang dengan dengan Bestuur Cabang Muhammadiyah Gorontalo, yang dipimpin oleh terdiri dari: Tom Olii, Jusuf Otoluwa, and Moh. Dunggio. Bestuur Cabang Muhammadiyah Gorontalo diresmikan dan dilantik pada tanggal 8 September 1929M bertepatan dengan 6 Rabiul Akhir 1348H, oleh Sekretaris Hoofbestuur Muhammadiyah Yogyakarta yaitu bapak Junus Anis. Hingga kini, Muhammadiyah Gorontalo telah memiliki struktur Pimpinan setingkat Wilayah (Propinsi), dan Pimpinan tingkat Daerah (kabupaten/kota) serta ortom-ortomnya.

\section{Al Huda dan Al Khairat (1929 Dan 1930)}

Perguruan Islam Al-Huda didirikan pada zaman Setelah Kemerdekaan Republik Indonesia pada tahun 1957 M. Sebagai lanjutan dari perguruan Islam AlFataa al-'Arabiyah di Kotamadya Gorontalo yang didirikan pada tahun 1929 M. ${ }^{22}$ Oleh karena kedua Taman Pendidikan Islam tersebut laksana untaian mata rantai yang tak terpisahkan.

Kata "Al-Fataa" berasal dari bahasa Arab berarti "pemuda", dan al-'Arabiyah artinya "bahasa Arab". Kalau dikembalikan kepada struktur tata bahasa Arab (ilmu Nahwu) maka sebenarnya lengkapnya menjadi "Madrasah Al-Fataa Al-'Arabiyyah" yang artinya "Sekolah Pemuda berbahasa Arab". Kata "al-Fataa" yang berarti pemuda dijadikan sebagai nama dari madrasah ini dikandung maksud agar kelak

\footnotetext{
${ }^{20}$ Ibrahim Polontalo. 1981. Muhammadiyah Setengah Abad di Gorontalo-Sejarah Perkekmbangan. PWM Sulut., h.10

21 Ibid., h. 14

${ }^{22}$ Sumber: Tim Penyusun, Instrumen Madrasah Unggulan 2014 Madrasah Tsanawiyah Al-Huda Kota Gorontalo Tahun 2014
} 
di masa depan madrasah ini tetap tegak dan tegar serta penuh semangat layaknya seorang "pemuda" yang selalu menjadi harapan generasi di masa datang mendakwahkan ajaran Islam lewat pendidikan. Selain itu para pendirinya adalah orang-orang yang memiliki semangat muda, pejuang, dan penyebar ajaran Islam dari negeri Arab di mana pada zaman itu telah banyak komunitas Arab yang datang dari negeri Yaman telah bermukim di sekitar tempat didirikannya madrasah ini.

Ide pendirian "Madrasah Al-Fataa al-'Arabiyah", sesungguhnya berangkat dari niat yang sangat luhur dari WNA (Warga Negara Asing) dalam hal ini para pemuda Arab pada waktu yang telah mulai membaur dan berasimilasi dengan penduduk Gorontalo, yang datang dengan tujuan berdakwah sambil berdagang. Menurut beberapa sumber dari kalangan keturunan Arab yang setelah kemerdekaan Indonesia mereka telah menjadi warga Indonesia, yang bermukim di kampung Arab (Kelurahan Limba B. Kota Gorontalo) bahwa pendirian "Madrasah Al-Fataa al-'arabiyah" awalnya adalah diperuntukkan dalam rangka mewadahi pemuda Arab yang datang dari negeri Yaman yang pada waktu itu masih belum lancar berbahasa Indonesia sehingga agak kesulitan dalam berkomunikasi dan menjalankan misi dakwahnya. Harapan besar dari para pendiri "Madrasah AlFataa al-'Arabiyah" ini, dengan adanya wadah tersebut para pemuda Arab akan semakin banyak menguasai bahasa Indonesia dengan baik melalui guru yang mereka tunjuk baik dari komunitas Arab yang lebih dahulu datang ke Gorontalo maupun dari orang Gorontalo langsung yang sudah agak memahami bahasa Arab. Dengan demikian tujuan luhur Dakwah Islamiyah para pemuda Arab yang baru datang saat itu akan semakin efektif, komunikatif dan cepat mengenai sasaran.

Khatim Podungge, mantan Qodhi Kwandang yang sekarang bertempat tinggal di Kelurahan Talumolo Kota Gorontalo dan sebagai mantan guru "Madrasah Al-Fataa al-'Arabiyah" tahun 1936-1939, menuturkan bahwa "Madrasah Al-Fataa Al-'Arabiyyah" adalah satu-satunya sekolah agama yang pertama kali dibuka di Gorontalo pada tahun 1929. Bahkan beliau mengistilahkan madrasah tersebut didirikan di Gorontalo, bukan hanya di Kotamadya Gorontalo, karena baik di Kotamadya maupun di Kabupaten Gorontalo pada zaman itu belum ada sama sekali sekolah agama sebelum adanya "Madrasah Al-Fataa Al-'Arabiyyah".

Menurut beberapa informasi yang disampaikan oleh H. Lukman Katili bawa tahun 1993: Tuan Guru Yahya Podungge seorang ulama sufi di bumi Gorontalo 
yang dikenal dengan panggilan "Ti Paci Nurjanah" menuturkan bahwa beliau pernah belajar di "Madrasah Al-Fataa Al-'Arabiyyah" dan pernah diajar oleh para Syekh antara lain oleh Syekh Abdul Rahiim, Syekh Mustafa, Syekh Abd. Rahman dan lain-lain. Beliau mengakui telah banyak menimba ilmu bahasa Arab dan ilmuilmu Islam dari "Madrasah Al-Fataa Al-'Arabiyyah" yang berada di Kelurahan Limba B Kota Gorontalo di mana kemudian tekenal dengan nama "Kampung Arab". Lebih lanjut menurut beliau "Madrasah Al-Fataa Al-'Arabiyyah" sebenarnya sudah ada sejak tahun 1921 M. Dan selang dari tahun 1921 sampai 1929 itulah beliau sedang giat-giatnya menimba ilmu agama Islam berbahasa Arab dengan kitabkitab kuning sebagai rujukannya, di "Madrasah Al-Fataa Al-'Arabiyyah" yang di kala itu masih biasa disebut "Taman Pengajian Al-Fataa al-'Arabiyah".

Dengan demikian, dapat dikatakan bahwa sebelum adanya "Madrasah AlFataa Al-'Arabiyyah", sekolah-sekolah agama di Gorontalo belum dikenal. Yang lebih dikenal di kala itu justru "sekolah rendah", dengan bahasa pengantar bahasa Melayu yang konon hanya beberapa buah di Gorontalo. Pada sekolah tersebut, mulai dari kelas 3 diajarkan huruf Arab Melayu atau huruf-huruf Pegon. Pada waktu itu, tidak ada sama sekali sekolah agama, baik mulai dari jenjang pendidikan yang paling dasar sampai pendidikan lanjutan atas. Ajaran Agama Islam saat itu masih terbatas diajarkan di di surau-surau, di mesjid-mesjid oleh para Imam dan Sara'a Da'a di tempat-tempat ibadah tersebut di mana terdapat kumpulan jama'ah, dan biasanya kegiatan itu dilakukan pada sore hari.

Dari berbagai sumber, dapat dikemukakan bahwa memang sejak tahun 1929 Madrasah Al-Fataa Al-'Arabiyyah telah cukup eksis di Gorontalo. Bahkan menurut Dr. Hamdan Ladiku, ternyata Habib Idrus bin Salim Al-Jufri yang terkenal dengan nama "Ustadz Tua" (pendiri Al-Khairaat di Palu tahun 1930) pernah datang ke Kampung Arab di Gorontalo pada ahun 1929. Habib yang kemudian terkenal luas sebagai 'Aalimu 'Allaamah', keturunan Rasulullah dari negeri Yaman ini diminta oleh komunitas bangsa Arab yang masih kerabat dan kawan-kawan beliau dari negeri Yaman yang sudah tinggal lama di kampung Arab Gorontalo, untuk menjadi guru tetap di "Madrasah Al-Fataa Al-'Arabiyyah". Dengan penuh hormat dan tawadlu' sang Habib menjawab permintaan itu dengan ungkapan: "Di Gorontalo ini sudah ada lampu, saya masih mencari daerah yang masih gelap gulita belum ada lampunya. Maksud beliau adalah di Goontalo sudah ada ulama, yakni rekan-rekan beliau sendiri yang mengajar di "Madrasah Al-Fataa Al-'Arabiyyah", 
cukuplah keberadaan mereka menjadi penerang, beliau sendiri akhirnya berdakwah di ibukota Sulawesi Tengah (Palu), yang kemudian berhasil mendirikan Al-Khairaat pada tahun 1930.

Sumber lain menyebutkan bahwa pada tahun 1929, karena pengaruh politik penjajah Belanda, maka komunikasi antara surau-surau dan mesjid dapat dikatakan sulit bahkan tidak ada sama sekali, intervensi Kolonial Belanda sangat kuat, rakyat dilarang berbicara politik. Melihat realita itu, tokoh-tokoh agama tidak tinggal diam, segala strategi mereka lakukan, salah satunya adalah dalam hal mengajarkan ajaran Islam, pelajaran difokuskan pada pembacaan kitab-kitab seperti pemahaman terhadap kandungan al-Quran serta dasar-dasar hukum fiqih, sasaran utamanya dititik beratkan pada masalah halal dan haram dengan maksud melepaskan diri dari kecaman dan belenggu penjajah. Pada tahun itulah, tepatnya tahun 1929, Madrasah Al-Fataa Al-'Arabiyyah secara resmi dikukuhkan sebagai sekolah agama atas inisiatif dari Bapak Haji Umar Basalamah dengan menyewa rumah milik dari Amir bin Badar yang terletak di Kampung Cina (Kelurahan Biawa'o Kota Gorontalo).

Seiring dengan berjalannya waktu Madrasah Al-Fataa Al-'Arabiyyah telah memperlihatkan kemajuannya berupa tingginya animo dan minat masyarakat Gorontalo yang itu dibuktikan dengan meningkatnya kuantitas peserta didiknya. Hal ini jelas membutuhkan sarana dan prasarana pendidikan yang lebih memadai dan dapat mengakomodir peserta didik, di samping juga mengingat rumah sewa yang selama ini digunakan tersebut sewaktu-waktu akan dibutuhkan kembali oleh pemiliknya. Dengan pertimbangan itu maka para pengurus yang dominan adalah para pemuda berketurunan Arab Yaman tersebut mengadakan rapat dan membahas tentang perluasan taman pendidikan Madrasah Al-Fataa Al-'Arabiyyah. Adapun para pengurus Madrasah tersebut antara lain: (1) H. Umar Basalamah (2) H. Said Bin Ahmad Djibran (3) H. Umar Bin Jusuf

Hasil yang diperoleh dari rapat itu adalah untuk membeli sebidang tanah yang terletak di Kelurahan Limba B Jl Ki. Mojo Nomor 26, dengan ukuran 75 x 75 M2. Belakangan, tanah tersebut telah menjadi lokasi Kampus Al-Huda sekarang ini. Di atas tanah tersebut dibangunlah Madrasah Al-Fataa Al-'Arabiyyah yang terdiri dari 3 kelas semi permanen.

Menurut salah satu sumber yaitu Habib Ahmad Bin Alwi Al-Masyhur, beliau menjelaskan bahwa pada tahun 1929 mula pertama para pelajar dididik di 
rumahnya Amir bin Badar. Beberapa bulan kemudian, dibangunlah Taman Pengajian Madrasah Al-Fataa Al-'Arabiyyah, sehingga semua kegiatan pembelajaran agama Islam yang ada di rumah-rumah tersebut dialihkan ke Madrasah Al-Fataa Al-'Arabiyyah. Lebih lanjut menurut beliau bahwa bangunan tersebut selesai pada tahun 1930, dengan tenaga pengajar sebagai berikut: (1) Syekh Muhammad Bin Umar Bahmid (2) Sayyid Ahmad bin Alwi Almasyur (3) Syekh Salim bin Umar Bahmid (4) Sayyid Abdullah Bin Umar Assagaf (5) Syekh Abdullah Bin Saleh Az-Zubedi

Adapun mata pelajaran yang diajarkan pada Madrasah Al-Fataa Al'Arabiyyah antara lain: (1) Loghah (bahasa Arab/ Muhadatsah) (2) Taarikh (Sejarah Islam) (3) Fiqih (4) Ushul Fiqih (5) Mufradat (6) Nahwu/Sharaf (7) Usul Hisab (8) Imla' (9) Tahsinul Khat (10) Tafsir Al-Quran

Dalam hal dana dan pembiayaannya, pengurus Madrasah Al-Fataa AlArabiyyah mengelola donatur bulanan dan uang pembayaran dari peserta didik dengan melibatkan langsung masyarakat terutama dari kalangan komunitas keturunan Arab yang mukim di kampung Arab dan sekitarnya, baik dalam bentuk donatur rutin maupun yang sifatnya wakaf, infak, sedekah, dan lain-lain yang halal dan tidak mengikat. Dengan demikian berlangsunglah Madrasah Al-Fataa Al'Arabiyyah tersebut dalam waktu yang cukup lama hingga kemudian berubah nama menjadi "Al-Huda".

Pada tahun 1932, didatangkan dua orang guru dari Ambon Provinsi Maluku masing-masing Ustadz Salim Bahmid dan Ustadz Mohammad Bahmid. Selanjutnya Pada tahun 1933 didatangkan pula seorang guru yang bernama Ustadz Hadi Addaba' sebagai kepala Madrasah dengan pembantu-pembantunya, seperti Abdullah Siraj, Zain Bin Mansyur, Khatim Podungge, Salim Alamri. Kemudian Pada tahun 1936 Madrasah Al-Fataa al-'Arabiyah berhasil menamatkan beberapa peserta didiknya, diantaranya adalah: Kiayi Haji Abas Rauf, Khatim Podungge, Abud Basalamah, Salim bin Umar Basalamah, Abdul Karim Badjeber, dan Abdul Bar Helingo.

Keenam orang lulusan Madrasah Al-Fataa al-'Arabiyah tersebut di kemudian hari telah mengharumkan nama almamaternya di Propinsi Sulawesi Utara dan Sulawesi Selatan. Adapun para alumni ini mendapat julukan: Lautan Ilmu (Bahrul 'Uluum) di Sulawesi Utara bagi alm. Kiyai Haji Abas Rauf dan Dosen 
Utama Bahasa Arab bagi alm. Abud Basalamah di Universitas Muslim Indonesia (UMI) di Ujung Pandang tahun 1979.

Pada tahun 1936 -1939, keadaan murid berkisar 40 orang, tetapi sayang Madrasah Al-Fataa Al-'Arabiyyah ditutup pada tahun 1940. Penutupan madrasah tersebut akibat meletusnya perang dunia kedua. Berselang lima tahun kemudian, madrasah ini dibuka kembali setelah gedung ini diperbaiki kerusakannya. Pada tahun 1945, kepala madrasah saat itu ialah Sayyid Sagaf Bin Syeh bin Salim Aljufri.

\section{Nahdatul Ulama}

Nahdhatul Ulama (NU) adalah Jam'iyyah Diniyah Islamiyah yang didirikan pada tanggal 16 Rajab 1344 H bertepatan dengan 31 Januari 1926 M di Surabaya. Organisasi ini dirintis dan didirikan oleh para ulama pesantren yang berhaluan Islam Ahlussunnah wal jama'ah dalam rangka mempersatukan diri dan menyatukan langkah dalam tugas memelihara, melestarikan, mengembangkan dan mengamalkan ajaran Islam serta khidmat kepada bangsa, negara dan ummat Islam.

Tujuan didirikannya NU adalah menegakkan ajaran Islam menurut paham "Ahlussunnah wal Jama'ah" di tengah-tengah kehidupan masyarakat, di dalam wadah Negara Kesatuan Republik Indonesia. Keterbelakangan baik secara mental, maupun ekonomi yang dialami bangsa Indonesia, akibat penjajahan maupun akibat kungkungan tradisi, telah menggugah kesadaran kaum terpelajar untuk memperjuangkan martabat bangsa ini, melalui jalan pendidikan dan organisasi. Gerakan yang muncul pada 1908 tersebut dikenal dengan "Kebangkitan Nasional". Semangat kebangkitan memang terus menyebar ke mana-mana - setelah rakyat pribumi sadar terhadap penderitaan dan ketertinggalannya dengan bangsa lain. Sebagai jawabannya, muncullah berbagai organisasi pendidikan dan pembebasan. 23

Bila ditelusuri motif utama yang mendasari gerakan para ulama membentuk NU ialah motif keagamaan sebagai jihad fii sabiilillah. Motif kedua adalah tanggung jawab pengembangan pemikiran keagamaan yang ditandai upaya pelestarian ajaran mazhab ahlussunnah waljama'ah. Ini tidak berarti statis, tidak berkembang, sebab pengembangan yang dilakukan justru bertumpu pada akar kesejarahan sehingga pemikiran yang dikembangkan itu memiliki konteks historis.

23 M. Ali Haidar, Nahdatul Ulama dan Islam di Indonesia, (Jakarta: PT.Gramedia Pustaka Utama, 1998), h. 314 
Motif ketiga ialah dorongan untuk mengembangkan masyarakat melalui kegiatan pendidikan, sosial dan ekonomi. Ini ditandai dengan pembentukkan Nahdatul Watan, Taswi-rul Afkar, Nahdatut Tujjar, dan Ta'mirul Masajid. Sedangkan motif keempat ialah motif politik yang ditandai semangat nasionalisme. ${ }^{24}$

Tujuan dan motif organisasi inilah yang menjiwai perkembangan organisasi ini di berbagai wilayah/provinsi di nusantara, tak terkecuali di wilayah Gorontalo. Secara historis, tersebutlah beberapa ulama terkenal yang telah berjasa dalam mengawal NU di masa awal di gorontalo, yaitu antara lain; (alm.) KH. Abas Rauf, (alm) KH. Adam Zakaria, H. D.K Usman, KH. Rasyid Kamaru dan H. Yusuf Mopangga. ${ }^{25}$ Amat disayangkan, penulis tidak berhasil menemukan informasi tentang awal berdirinya organisasi ini di Gorontalo. Namun fakta menunjukkan bahwa umat Islam Gorontalo mayoritas menganut faham NU. Dan secara fakta pula organisasi ini berdiri dan memiliki pengurus dari tingkat provinsi maupun kabupaten dan kota hingga saat ini. Eksistensi organisasi dan pengurus inilah yang secara terus menerus dari generasi ke generasi menjalankan ajaran-ajaran ke-NUan di tengah masyarakat, termasuk menjalankan misi dakwah.

Untuk mewujudkan tujuan organisasi, NU melakukan usaha-usaha; pertama, Di bidang agama mengusahakan terlaksananya ajaran Islam menurut faham Ahlussunnah wal jama'ah dalam masyarakat dengan melaksanakan dakwah islamiyah dan amar ma'ruf nahi munkar serta peningkatan ukhuwah islamiyah.

Di bidang Pendidikan, pengajaran dan kebudayaan mengusahakan terwujudnya penyelenggaraan pendidikan dan pengajaran serta pengembangan kebudayaan yang sesuai dengan ajaran Islam, untuk membina manusia muslim yang taqwa, berbudi luhur, berpengetahuan luas, dan terampil serta berguna bagi agama, bangsa dan negara.

Di bidang sosial, mengusahakan terwujudnya pembangunan ekonomi dengan dengan mengupayakan keadilan sosial dan keadilan hukum disegala lapangan bagi seluruh rakyat untuk menuju kesejahteraan dan keselamatan umat di dunia dan akhirat. Di bidang ekonomi, mengusahakan terwujudnya pembangunan ekonomi dengan mengupayakan pemerataan kesempatan untuk

${ }^{24}$ Kuntowidjoyo, Dinamika Sejarah Ummat Islam Indonesia, (Yogyakarta: Salahuddin Press, 1985), h. 16

${ }^{25} \mathrm{KH}$. Rasyid Kamaru, Dai dan Kiayi NU Provinsi Gorontalo, wawancara, tanggal 15 September 2018. 
berusaha dan menikmati hasil-hasil pembangunan, dengan mengutamakan tumbuh dan berkembangnya koperasi.

Berkaitan dengan strategi dakwah yang dikembangkan oleh NU, maka pada tataran implementasinya sangat dipengaruhi oleh model pemikiran dan prilaku (manhaj al-fikr wa sirah) dalam pembumian ajaran Islam yang bertumpu pada tiga sikap/karakter dalam beragama: (1) Tawassuth (moderat) yaitu sikap tengah yang berintikan pada prinsip hidup yang menjunjung tinggi keharusan berlaku adil dan lurus di tengah kehidupan tanpa mengambil sikap ekstrim (tatharruf). Implementasi sikap ini dalam konteks hukum adalah keseimbangan dalam menggunakan wahyu dan akal dan dalam konteks aqidah tidak gampang memberikan vonis kafir, sesat kepada orang lain. Mengambil sikap tengah antara: wahyu dan akal, Taqdir dan ikhtiyar dan antara taqlid dan ijtihad. (2) Tawazun dan Ta'adul (keseimbangan) sikap ini terepleksi dalam tata pergaulan baik dimensi politik maupun budaya.(3) Tasamuh (toleran) yaitu mengembangkan dan menumbuhkan sikap menghormati keragaman pemahaman, tindakan maupun gerakan dalam konteks keislaman. Prinsip ini dimaksudkan dalam upaya membangun ukhuwwah baik ukhuwwah Islamiyah, Basyariyah maupun Wathaniyah. ${ }^{26}$

Pendekatan kultural dalam gerakan dakwah NU dimaknai sebagai upaya pembumian ajaran Islam dengan menggunakan perangkat budaya lokal sebagai instrumen dakwahnya. Inilah yang mendasari gerakan dakwah NU di Nusantara yang lebih banyak bergelut dengan tradisi atau adat istiadat setempat sebagai sarana dakwahnya. Tak terkecuali di Kota Gorontalo. Melalui tradisi dan adat istiadatlah jamaah NU Gorontalo dapat diidentifikasi identitasnya dan mudah dikenali praktek keagamaannya. Melalui jalur tradisi dan adat istiadat pula ajaranajaran NU terus diwariskan di setiap generasi.

Daerah Gorontalo yang kental dengan praktek-praktek adat dan tradisi dalam pengamalan ajaran Islam seakan menjadi tanah subur bagi tumbuh dan berkembangnya dakwah kultural NU. Hal ini juga dibenarkan oleh salah seorang pengurus NU di Kota Gorontalo, KH. Lukman Katili:

\footnotetext{
${ }^{26}$ Muhammad Tholhah Hasan, Ahlussunnah Wal-Jama'ah; dalam Persepsi dan Tradisi NU, (Jakarta: Lantabora Press, 2005), h. xiii .
} 
"Gorontalo tidak bisa dipisahkan dari adatnya, demikian pula NU, tidak bisa dipisahkan dari adat dan tradisi Gorontalo. Jadi dakwah NU itu adalah dakwah melalui kultur. Semua kegiatan manusia di Gorontalo ini tidak lepas dari aturanaturan adat, dan semua adat-adat itu bersumber dari ajaran Islam murni. Dari orang lahir sampai orang meninggal ada ritual adatnya, semua memiliki bacaan doa, wirid dan zikirnya. Artinya, warga NU itu dalam semua hajat dan aktifitasnya senantiasa mengamalkan ajaran Islam. Itulah dakwah dalam rutinitas warga NU". ${ }^{27}$

Pengamalan adat dan tradisi dalam masyarakat Kota Gorontalo masih sangat umum dan dipraktekkan oleh mayoritas Umat Islam. Karena itu untuk mengamati identitas ke-NU-an masyarakat, cukup dengan mengamati apakah masyarakat tersebut mengamalkan adat dan tradisi dalam kesehariannya. Untuk saat sekarang ini dapatlah dikatakan bahwa adat dan tradisi tersebut masih sangat melekat dengan masyarakat Gorontalo atau sebagai warga NU.

Munculnya gerakan-gerakan dakwah organisasi Islam lain, baik yang berhaluan salaf maupun modern belum cukup kuat mempengaruhi pendirian masyarakat warga NU untuk meninggalkan doktrin dan ajarannya. Namun juga bukan berarti gerakan dakwah NU hanya fokus pada persoalan-persoalan tradisi dan sering diidentikkan dengan faham tradisional seperti itu. Gerakan dakwah NU, khususnya di tingkat Pengurus Wilayah Provinsi Gorontalo saat ini semakin mengembangkan usaha dakwah yang terbilang modern, seperti melakukan penyegaran seluruh pengurus di tingkat kabupaten/kota untuk lebih meningkatkan pelayanan dakwah kepada kaum Nahdliyyin di Gorontalo. Termasuk pula yang saat ini sementara diperjuangkan, yaitu pendirian Universitas Nahdlatul Ulama Gorontalo yang sudah di ambang peresmian. Usaha-usaha ini merupakan usaha dakwah NU dalam merespon kebutuhan umat dan sekaligus tuntutan perkembangan. ${ }^{28}$ Senada dengan pemikiran tersebut, Ketua NU Kota Gorontalo juga mengungkapkan bahwa saat ini usaha dan amal NU terus dikembangkan mengikuti perkembangan kebutuhan warga NU. Bila pengurus tidak mampu merespon perkembangan yang ada, dikhawatirkan jamaah dan warga NU akan dengan mudah terbawa arus perkembangan zaman saat ini. ${ }^{29}$

\footnotetext{
${ }^{27}$ KH. Lukman Katili, M.Fil.I, Dai dan Kiayi NU Provinsi Gorontalo, wawancara, tanggal 17 September 2017.

${ }^{28}$ Dr. Zulkarnain Suleman, M.Hi., Ketua Pimpinan Wilayah NU Provinsi Gorontalo, wawancara, tanggal 11 September 2018.

${ }^{29}$ Drs. Ibrahim T. Sore, Ketua Pimpinan Cabang NU Kota Gorontalo, wawancara, tanggal 11 September 2018.
} 
Dengan demikian penulis berkesimpulan bahwa gerakan dakwah NU yang berbasis dakwah kultural di samping diarahkan untuk peningkatan kualitas keislaman juga sekaligus sebagai upaya mengembangkan budaya sebagai ciri dan kepribadian masyarakat Gorontalo. Lebih dari itu pula mempertahankan jati diri dan nilai-nilai utama budaya menjadi benteng yang efektif menghindarkan diri dari gempuran arus informasi dan pengaruh negatif budaya global. Karena itulah gerakan dakwah NU Gorontalo saat ini tidak dapat difahami sebagai gerakan dakwah tradisional. Terbukti dakwah kultural sebagai ciri khas dakwah NU senantiasa di up date untuk merespon perkembangan yang terus terjadi.

\section{Kesimpulan}

Sebagai kesimpulan studi ini bahwa, pertama, konstruksi jaringan islamisasi Gorontalo pada masa awal keislaman (fase pertama islamisasi Gorontalo), ditandai dengan Raja Amai, raja utara yang ke II kerajaan Gorontalo pada tahun 1525, melakukan perjalanan dinasnya ke daerah-daerah jajahan Gorontalo tersebut, yakni di Teluk Tomini Barat dan kawin disana, tepatnya di daerah Palasa. Dalam perjalanan dinasnya di Palasa tersebut, Sultan Amai bertemu dengan puteri raja Palasa (bergelar Ogomonjolo; bermakna yang punya sifat air dingin) yang bernama Owutango, yang sudah menerima Islam dari Kesultanan Ternate. Islam menjadi agama resmi kerajaan pada zaman pemerintahan Raja Matolodulakiki, yang mengedepankan prinsip 'adat bersendi syara', syara bersendi kitabullah". Prinsip penyebaran Islam pada masa ini melahirkan suatu perkembangan baru yakni adat yang di Islam-kan atau Islam yang diadat-kan. Prinsip di atas lantas disempurnakan oleh Eyato, raja Gorontalo, sejak tahun 1673 menjadi " Adati hula-hulaa to saraa, saraa hula-hulaa to Kur'ani" (ASQ). Landasan ini membawa implikasi tak ada lagi pertentangan antara apa yang diajarkan oleh adat dan Islam. Wujud dari landasan tersebut tergambarkan dalam sistem sosial dan pemerintahan yang dibangun oleh Raja Eyato. Konsep kekuasaan Eyato ada dua, yaitu kekuasaan lahir yang dipraktikkan sehari-hari dan kekuasaan batin yang ada di dalam masyarakat. Namun, yang utama dari dua kekuasaan tersebut adalah kekuasaan batin. Ini berarti penguasa harus memusatkan kerjanya kepada kepentingan masyarakat. Konteks tersebut menkonfirmasi jeringan islamisasi Gorontalo adalah Islam Gorontalo dari Palasa (Tomini), dari Ternate, dari Giri dan Aceh. 
Akhirnya, corak jaringan islamisasi Gorontalo pada masa perkembangan berdasarkan realitas keagamaan. Pada fase kedua islamisasi Gorontalo yakni ditandai dengan berkembangnya pengajaran Islam dikalangan masyarakat Gorontalo yang bercorak tarekat/sufistik (mistisisme) yakni dimasa pemerintahan raja Eyato dan anaknya raja Ilato Ju Panggola. Pada masa itu hadir guru agama Islam (guru tasawuf) dari Mekah yang bernama Syekh Syarif bin Abd. Aziz, yang menurut riwayat beliau adalah pemegang kunci pintu ka'bah dan belajar Islam dari aliran tarekat Qadiriyah yang didirikan oleh Syekh Abdul Qadir Jailani (10761169). Di samping itu islamisasi Gorontalo di masa itu juga dipengaruhi oleh Islam yang menyebar melalui konflik panjang antara kerajaan Limboto dan kerajaan Gorontalo, yang mana dibalik konflik tersebut hadir pula pihak sekutu yakni kesultanan Ternate dan kesultanan Gowa yang member pengaruh terhadap perkembangan Islam Gorontalo. Konteks demikian dapat dipahami bahwa pada fase kedua islamisasi Gorontalo adalah; Jalur I; Gorontalo dari Mekah. Jalur II; Gorontalo dari Ternate dan Makassar, Ternate dari Aceh dan Giri, sedang Makassar dari Islam Minang. Adapun fase ketiga islamisasi Gorontalo adalah pada awal abad 20, yakni dimulai pada tahun 1929 ketiga Muhammadiyah mulai berdiri di Gorontalo melalui pendirin cabang pertamanya. Pada tahun 1929, berdiri ormas Islam lainnya yang menjadi cikal bakal perguruan al-Huda dan al-Khairat pada tahun 1930. Selanjutnya Nahdatul Ulama juga hadir diawal tahun 70an (tidak ada data yang otoritatif mengenai sejarah NU di Gorontalo) memperkuat proses islamisasi Gorontalo di masa perkembangan. Konteks tersebut dapat disimpulkan bahwa pada fase ketiga islamisasi Gorontalo melalui jalur: Gorontalo dari Yogyakarta, Gorontalo dari Yaman, Gorontalo dari Palu, dan Gorontalo dari Jawa Timur.

\section{DAFTAR PUSTAKA}

Abdullah, Taufik dan M. Rusli Karim (eds.). 1989. Metodologi penelitian agama: sebuah pengantar. Yogyakarta: Tiara Wacana.

Ancok, Djamaluddin \& Suroro, Fuad Nashori. 1995. Psikologi Islam. Yogyakarta: Pustaka Pelajar.

Azra, Azyumardi. 1994. Perspektif Islam di Asia Tenggara. Jakarta: Yayasan Obor.

Azra, Azyumardi. 2018. Jaringan Ulama Timur Tengah dan Kepulauan Nusantara Abad XVII \& XVIII. Jakarta: Prenada Media.

Baker, Chris 2005. Cultural studies. Yogyakarta: Kreasi Wacana. 
Bakry, Muhiddin. 2016. Nilai religiousitas adat Mo Me'ati pada masyarakat Kota Gorontalo (Replika Islam Nusantara). Al-Ulum, Vol. 16, No.2, pp. 185-207.

Barnard, Alan \& Spencer, Jonathan. 2002. Encyclopedia of social and cultural Anthropology. New York: Routledge.

Connolly, Peter (ed.) 2011. Aneka Pendekatan Studi Agama. Yogyakarta: LKiS.

Ember, Carol R \& Ember, Malvin. 1977. Anthropology. New Jersey: Prentice-Hall.

Erniwati. 2011. China Padang dalam dinamika masyarakat Minangkabau: dari revolusi sampai Reformasi. Jakarta: Universitas Indonesia.

Foccardi, Gabriele. 1986. The Chinese travelers of the Ming periode. Dalam Tan Ta Sen. 2010.

Ghafur, Abdul. 2011. Telaah kritis masuk dan berkekmbangnya Islam Nusantara. Jurnal Ushuluddin, Vol. XVII, No.2.

Graaf, De. 2013. "Islam di Asia tenggara Abad ke-18”. Dalam Muhammad Mustdla (ed.) Perspektif Islam di Asia Tenggara. Jakarta: Kemenag. R.I.

Haga, B.J. 1994. De lima Pohalaa (Gorontalo) volksordering adatrecht en Bastuur Politick. (Terjemahan). Jakarta: Jambatan

Haidar, M. Ali. 1998. Nahdatul Ulama dan Islam di Indonesia. Jakarta: PT.Gramedia Pustaka Utama.

Hasan, Muhammad Tholhah. 2005. Ahlussunnah Wal-Jama'ah; dalam persepsi dan tradisi NU. Jakarta: Lantabora Press.

Husnan, Moh Ihsan. 2012. Pohutu Momulanga: gelar adat di Gorontalo. Al-Ulum, Vol. 12, No.1, pp. 175-200.

Kuno, Kaluku. TT. Adat dan agama Islam. (Gorontalo: T.P.)

Kuntowidjoyo. 1985. Dinamika sejarah ummat Islam Indonesia. Yogyakarta: Salahuddin Press.

Marcus, A.S. 2009. Hari-hari raya Tionghoa. Jakarta: Suara Harapan Bangsa.

Mopangga, A. 1997. Sejarah kampung empat; Siduan, Sipayo, Soginti, Bunuyo. (Makalah).

Nur, S.R. 1979. Beberapa aspek hukum adat tata negara Kerajaan Gorontalo pada masa pemerintahan Eyato (1673-1679). Ujung Pandang: Disertasi Unhas.

Nur, S.R. 1996. Islam dan etos kerja masyarakat Gorontalo. Jakarta: Yayasan Festival Istiqlal.

Polontalo, Ibrahim. 1968. Peranan Tidi Lopolopalo Gorontalo dalam pembinaan kepribadian suku Gorontalo. Menado: FKPS-IKIP.

Polontalo, Ibrahim. 1981. Muhammadiyah setengah abad di Gorontalo - sejarah perkekmbangan. Sulawesi Utara: PWM.

Polontalo, Ibrahim. 1997. Proses masuk dan berkembangnya agama Islam di Gorontalo, Makalah. 
Rahman, M Gazali Rahman. 2012. Tradisi Mothulo di Gorontalo, Al-Ulum, 2012, vol.12, no. 2, pp. 437-456.

Rodrigues, Hillary \& Harding, John S. 2009. Introduction to the study of religion. New York: Routledge.

Rusli, Muh. 2016. Persepsi masyarakat tentang makam Raja dan Wali Gorontalo. El-Harakah, Vol. 18, No. 1, pp. 78-93.

Rusli. 2008. Pendekatan fenomenologi dalam studi agama konsep, kritik dan aplikasi. Islamica, Vol. 2, No. 2, pp. 141-153

S.R. Nur. 1979. Beberapa aspek hukum adat tata negara Kerajaan Gorontalo pada masa Pemerintahan Eyato (1673-1679). Ujung Pandang: Disertasi Unhas.

Saifuddin, Ahmad Fedyani. 2006. Antropologi Kontemporer. Jakarta: Kencana Prenada Group.

Sewang, Ahmad M. 2005. Islamisasi Kerajaan Gowa: Abad XVI sampai abad XVII. Jakarta: Yayasan Obor Indonesia.

Suryanegara, Ahmad Mansur. 2002. Menemukan sejarah, wacana pergerakan Islam di Indonesia. Bandung: Mizan.

Taba, Abdul Aziz, 1998. Islam dan negara dalam politik Orde Baru. Jakkarta: Gema Insani Press.

Tim Penyusun. 2014. Instrumen Madrasah Unggulan 2014 Madrasah Tsanawiyah Al-Huda Kota Gorontalo Tahun 2014. Gorontalo: Al-Huda.

Tugiyono. 1982. Atlas dan lukisan sejarah Nasional Indonesia. CV. Baru; Jakarta.

Yasin, Zohra dkk. 2013. Islam Tradisi dan Kearifan Lokal Gorontalo. Gorontalo: Sultan Amai Press. 